\title{
History of Science in Egodocuments: The Letters of Dr. Jonas Basanavičius in a Bibliographical Dataset
}

The Wroblewski Library of the Lithuanian Academy of Sciences (WLLAS) is known for the experience in creating bibliographical indexes and datasets. Bibliographical indexing here dates back to 1956, when the first bibliographical index was published. The first personal bibliographical index was published in 1972. The electronic library system ALEPH was adopted for bibliographical records in 2005. The bibliographical datasets Lithuanian History, Lithuanian Philology and Kristijonas Donelaitis (1714-1780, a founder of Lithuanian fiction) can be openly accessed at the library's website (The Wroblewski Library, n.d.).

Currently, a bibliographical dataset for Dr. Jonas Basanavičius (1851-1927), a distinguished Lithuanian politician, is being compiled at the Wroblewski Library of the Lithuanian Academy of Sciences. His name is well known not only in the history of science in Lithuania, but also in the history of political ideas and struggles for the independence of Lithuania. Basanavičius was a versatile personality, distinguished in various fields. He was the pioneer of the Lithuanian national revival, one of the most determined seekers of the independence of Lithuania, a physician, a specialist in folk-linguistic heritage, a historian, a prominent public and cultural figure.

Basanavičius collected, investigated, prepared for the press and published thousands of songs and narrated folklore works; he defended the rights of the Lithuanian language, which he extensively studied and compared to the ancient Thracian language; he paid much attention to education of Lithuanians in their native Lithuanian language, and fostered Lithuanian press. Basanavičius wrote about the past of Lithuania and linked it to the future of the nation, encouraging society to work for the common good of the homeland and the state.

Dr. Basanavičius developed a wide international scholarly cooperation, corresponded with famous European historians, specialists of philology and historians of medicine in Europe. The letters he received are stored in the library of the Institute of Lithuanian Literature and Folklore. A reconstruction of his library was created, a catalogue was published (Narbutas \& Narbutiené, 2008). 
Striving to honour the memory of this outstanding figure in the history of the Lithuanian nation, WLLAS developed a project to compile a comprehensive index of works by Jonas Basanavičius and literature about him. The first part of the bibliography, covering the works written by Basanavičius himself, was published already in 2015 (Kulikauskienè, 2015). The second part, which should encompass published literature about his life and activities, is still in work. The book will be available in a paper format.

In order to increase and facilitate access to the bibliographical index, and also to expand possibilities for information retrieval and dissemination, Jonas Basanavicius Bibliographical Index is prepared not only for print, but also in electronic form, using the latest automated recording and dissemination technologies.

At present, the dataset contains over 15,000 bibliographical records. It will be launched after the release of the second part of Jonas Basanavicius Bibliographical Index. The dataset will be constantly updated with the latest information.

The dataset contains records on publications of different volume, genre and content, including Basanavičius' correspondence with Lithuanian and foreign scholars, public and cultural figures. The Lithuanian scholar was characterized, in his academic career, by extensive scientific contacts with researchers of European history, linguistics, and medical history. The dataset contains information on more than 580 letters from Basanavičius and 650 letters written to him. It should be noted that only published letters are registered, as it was decided not to include manuscript material in the bibliography and dataset. Since numerous Basanavičius' manuscripts are scattered in various Lithuanian and foreign archives, such work would take a lot of time and effort. Therefore, it was agreed that records for manuscript materials will be added to the dataset at some future time.

The dataset is created within a platform of a library system ALEPH, the bibliographical records are created in MARC21 format. Metadata for the letters include: the author of the letter; title (including the first words of the letter); place and date of creation; name of the addressee; data of the source in which the letter was published (title, creators, place of publication, publisher and year of publication); language of the letter.

After organizing and editing the collected material, a search engine for information search will be created. It will provide search options by title, personal name 
(author or another person of responsibility), title of a source, its publishing place and year; also any word or several words in a record.

The search will be facilitated by indexes: titles, authors and other persons of responsibility, titles of sources, place of publication and language of the letter. An index of persons will list the letters by author or addressee.

In a process of publishing, the WLLAS uses auxiliary publishing software to generate a book form from dataset records. Bibliographers were involved in a process of development of the software, together with IT specialists. The bibliographers were responsible for a detailed specifications which stated:

- The sequence of elements of a bibliographical entry;

- The format of certain elements (highlighted, italic, different font size);

- The sequence of grouping records within a certain chapter of the publication;

- The sequence of chapters in the publication;

- The output rules for auxiliary indexes (personal names, place names, associations, titles).

Following the given specifications, the IT specialists developed a publication program. This program is an indispensable tool for bibliographers-it builds the layout of the publication in a matter of minutes.

The bibliographical dataset discussed above is an important and valuable source of information for scholars investigating the personality of Jonas Basanavičius, for specialists of literature, history, scientometrics, etc. It will both facilitate the studying of the scholarly, cultural and civic activities of Basanavičius and throw light on the historical, political and cultural circumstances of that period.

Translated from Lithuanian by Birute Railiene

\section{Giedrè Miknienè}

The Wroblewski Library of the Lithuanian Academy of Sciences 


\section{References}

Kulikauskienè, J., comp. (2015), Jonas Basanavičius: bibliografijos rodykle, D. 1, Jono Basanavičiaus darbai, Vilnius: Lietuvos mokslų akademijos Vrublevskiu biblioteka.

Narbutas, S. \& Narbutienè, D., comp. (2008), Jono Basanavičiaus asmeninès bibliotekos katalogas, XXXVII, Vilnius: Lietuviu literatūros ir tautosakos institutas.

The Wroblewski Library (n.d.), Catalogues, The Wroblewski Library of the Lithuanian Academy of Sciences. Retrieved from http://www.mab.lt/lt/katalogai [accessed Nov 2018] 